\title{
GENETIC DIVERSITY OF BEGOMOVIRUS INFECTING TOMATO AND ASSOCIATED WEEDS IN SOUTHEASTERN BRAZIL
}

\author{
LUCIANA P. AMBROZEVICIUS ${ }^{1 *}$, RENATA F. CALEGARIO ${ }^{1}$, ELIZABETH P.B. FONTES ${ }^{2 * *}$, \\ MURILO G. DE CARVALHO ${ }^{1} \&$ F. MURILO ZERBINI ${ }^{1 * *}$
}

\begin{abstract}
${ }^{1}$ Departamento de Fitopatologia/BIOAGRO, ${ }^{2}$ Departamento de Bioquímica e Biologia Molecular/BIOAGRO, Universidade Federal de Viçosa, CEP 36571-000, Viçosa, MG, e-mail: zerbini@ufv.br
\end{abstract}

(Accepted for publication 15/03/2002)

Corresponding author: F. Murilo Zerbini

AMBROZEVICIUS, L.P., CALEGARIO, R.F., FONTES, E.P.B., CARVALHO, M.G. \& ZERBINI, F.M. Genetic diversity of begomovirus infecting tomato and associated weeds in Southeastern Brazil. Fitopatologia Brasileira 27:372-377.. 2002.

\begin{abstract}
The genetic diversity of begomovirus isolates from tomato (Lycopersicon esculentum) fields in the Southeastern region of Brazil was analyzed by direct sequencing of PCR fragments amplified by using universal oligonucleotides for the begomovirus DNA-A, and subsequent computer-aided phylogenetic analysis. Samples of tomato plants and associated weeds showing typical symptoms of virus infection were collected at seven locations in the states of Minas Gerais, Espírito Santo and Rio de Janeiro. A total of 137 out of 369 samples were infected with a begomovirus based on PCR analysis. Phylogenetic analysis indicated a high degree of genetic diversity among begomoviruses infecting tomatoes in the sampled area. One

species (Tomato chlorotic mottle virus, TCMV) occurs predominantly in Minas Gerais, whereas in Rio de Janeiro and Espírito Santo a distinct species, not yet fully characterized, predominates. Phylogenetic analysis further indicates the presence of an additional four possible new species. This high degree of genetic diversity suggests a recent transfer of indigenous begomovirus from wild hosts into tomatoes. The close phylogenetic relationship verified between begomovirus infecting tomato and associated weeds favors this hypothesis.

Additional keywords: Geminiviridae, phylogenetic relationships, Tomato chlorotic mottle virus.

\section{RESUMO}

\section{Diversidade genética de begomovirus infetando o tomateiro e plantas daninhas no Sudeste do Brasil}

A análise da variabilidade genética de geminivírus infetando tomateiros (Lycopersicon esculentum) na região Sudeste do Brasil foi realizada por meio do seqüenciamento direto de fragmentos de PCR amplificados com oligonucleotídeos universais para o componente A de begomovírus, seguido de análise filogenética. Amostras de tomateiro e de algumas plantas daninhas associadas, apresentando sintomas típicos de infecção por vírus, foram coletadas em sete municípios nos estados de Minas Gerais, Espírito Santo e Rio de Janeiro. Após extração de DNA total e PCR, verificou-se que 137 amostras estavam infetadas por begomovírus, de um total de 369 amostras coletadas. A análise filogenética indicou existir

uma grande diversidade genética de begomovírus em tomateiros nas três regiões amostradas, com a predominância de uma espécie viral (Tomato chlorotic mottle virus, TCMV) na Zona Metalúrgica de MG, enquanto no RJ e ES predomina uma outra espécie não completamente caracterizada. A análise filogenética indicou ainda a presença de outras quatro possíveis novas espécies de begomovírus em tomateiro. $\mathrm{O}$ alto grau de diversidade genética encontrado sugere uma transferência recente de begomovirus a partir de hospedeiros silvestres para o tomateiro. O relacionamento filogenético encontrado entre os begomovirus de tomateiro e isolados virais obtidos a partir de plantas daninhas favorece essa hipótese.
\end{abstract}

\section{INTRODUCTION}

Begomoviruses are characterized by their unique particle morphology of twinned incomplete icosahedra and a genome composed of circular, single-stranded DNA (HanleyBowdoin et al., 1999; Faria \& Zerbini, 2000). The family Geminiviridae is composed of four genera, based on the number of genomic components, type of insect vector, host range and phylogenetic relationships: Mastrevirus, Curtovirus, Begomovirus, and Topocuvirus (Van Regenmortel

*Part of the M.S. thesis of the first author. Universidade Federal de Viçosa **CNPq fellow. et al., 2000). Geminiviruses in general, but specially those belonging to the genus Begomovirus, are considered to be emerging plant viruses, due to their increasing incidence and the severity of the diseases they cause in a number of economically important crops, mostly in tropical and subtropical regions of the world (Polston \& Anderson, 1997; Faria et al., 2000). More than 20 species of geminiviruses, mostly begomoviruses, have been described as capable of infecting tomato (Lycopersicon esculentum Mill.). Since the 1980 's, substantial losses have been reported in many regions of the Americas, including Florida (USA), Mexico, the Caribbean, Central America, and Venezuela (Polston \& Anderson, 1997). 
Begomoviruses infecting tomato were first reported in Brazil by Costa et al. (1975). Matyis et al. (1975) purified the virus, named Tomato golden mosaic virus (TGMV). The occurrence of TGMV in tomatoes was always low, probably because its insect vector, the whitefly Bemisia tabaci Genn. biotype A, rarely colonizes tomato plants. However, in the early 1990's, the presence of a new biotype of B. tabaci (biotype B) was reported in Brazil, initially in São Paulo, and then in several other states (França et al., 1996). The B biotype has a wider host range than the A biotype of B. tabaci, readily colonizing solanaceous hosts, including tomato (Bedford et al., 1994).

Probably as a consequence of the quick dissemination of the B biotype of B. tabaci throughout Brazil, several reports on begomovirus outbreaks in tomatoes have occurred since 1994 in a number of states, including Minas Gerais, São Paulo, Pernambuco, Bahia, and the Federal District (reviewed by Faria et al., 2000). Partial characterization of the viruses associated with these outbreaks, including sequencing of the 5 ' end of their capsid protein gene (a region that is representative of the sequence variability of the entire viral genome), suggested that several new begomovirus species were emerging in Brazil (Ribeiro et al., 1998). A more comprehensive phylogenetic analysis indicated the presence of at least five, and possibly seven new begomovirus species associated with tomatoes in Brazil (Ribeiro et al., 2002).

The objective of this work was to carry out a detailed study of the incidence and genetic diversity of begomoviruses infecting tomato and associated weeds in fields located in the states of Minas Gerais (MG), Rio de Janeiro (RJ) and Espírito Santo (ES).

\section{MATERIALS AND METHODS}

\section{Collection of samples}

Tomato samples were collected from June through November of 1999 in fields located around the cities of Igarapé, Mateus Leme, and Bicas (the green belt of Belo Horizonte, MG), Várzea Alegre (ES), São Fidélis (Northern RJ) and Paty do Alferes (Southern RJ) (Table 1). Young leaves from 15 plants showing typical symptoms of begomovirus infection (yellow mosaic, leaf curling, and stunting) were collected from each field, except in Paty do Alferes, where 20, 24 and 25 samples were collected in each of the three fields sampled (Table 1). A number of weed samples were also collected. Samples were placed in plastic bags and taken to the laboratory, where they were wrapped in aluminum foil, labeled and stored at $-80^{\circ} \mathrm{C}$.

\section{DNA extraction and PCR}

Total DNA was extracted from $1 \mathrm{~cm}$ leaf disks, according to Dellaporta et al. (1983). Begomovirus infection was verified by PCR, using the begomovirus universal primers PAL1v1978 and PAR1c496 (Rojas et al., 1993). These primers direct the amplification of a DNA-A fragment comprising the 5' end of the rep gene, the entire common region and the
5 ' end of the capsid protein ( $c p$ ) gene. PCR reactions were prepared in a $25 \mu \mathrm{l}$ volume, containing $10 \times$ buffer $(100 \mathrm{mM}$ Tris- $\mathrm{HCl}, 500 \mathrm{mM} \mathrm{KCl}, \mathrm{pH} 8.3), \mathrm{MgCl}_{2}(75 \mathrm{mM})$, dNTP mix $(4 \mathrm{mM}), 10 \mu \mathrm{M}$ of each primer, 1 unit of Taq DNA polymerase and $5 \mu \mathrm{l}$ of the DNA template. The amplification profile consisted of 30 cycles of denaturing at $94{ }^{\circ} \mathrm{C}$ for 1 min, primer annealing at $55^{\circ} \mathrm{C}$ for $2 \mathrm{~min}$ and primer extension at $72^{\circ} \mathrm{C}$ for $2 \mathrm{~min}$. PCR products were visualized in agarose gels $(0.9 \%)$ stained with ethidium bromide under UV light.

\section{Direct sequencing of PCR products}

In order to obtain larger amounts of DNA for the sequencing reaction, new PCR reactions were carried out in a $100 \mu \mathrm{l}$ volume, with the same components described above and using the same amplification profile. Amplification products were purified using the Concert Rapid PCR Purification System (GibcoBRL), and the DNA concentration was estimated in agarose gels $(0.9 \%)$. Sequencing reactions were prepared using the BigDye Terminator Cycle Sequencing Ready Reaction kit (Perkin Elmer) in a $20 \mu \mathrm{l}$ volume, containing $10 \mu \mathrm{M}$ of the PAR1c496 primer and $150 \mathrm{ng}$ of template DNA. The reaction profile consisted of an initial denaturing step at $96^{\circ} \mathrm{C}$ for $3 \mathrm{~min}$, followed by 25 cycles of denaturing at $96^{\circ} \mathrm{C}$ for $40 \mathrm{sec}$, primer annealing at $55^{\circ} \mathrm{C}$ for $20 \mathrm{sec}$ and primer extension at $60^{\circ} \mathrm{C}$ for $4 \mathrm{~min}$. Reactions were analyzed in an ABI 310 automated sequencer (Applied Biosystems). Two independent reactions were sequenced for each isolate.

\section{Phylogenetic analysis}

Pair wise sequence analysis was carried out using the GCG software package (Devereux et al., 1984). Database searches were carried out with BLASTn (http://www.ncbi. nlm.nih.gov/BLAST). Multiple sequence alignments were prepared with Clustal W (http://www.ebi.ac.uk/clustalw). Phylogenetic trees were prepared with MEGA version 2.0 (http://www.megasoftware.net).

\section{RESULTS AND DISCUSSION}

The presence of a begomovirus was confirmed in 137 out of 369 tomato samples collected. In Minas Gerais, 44\% of the samples were infected: $24 \%$ infected at Igarapé, $51 \%$ at Bicas, $53 \%$ at Mateus Leme and $67 \%$ at Serra Azul. In Várzea Alegre (ES), the percentage of begomovirus infected plants reached 32\%, and in São Fidélis (RJ) it reached 64\% of the samples collected (Table 1). Surprisingly, no begomovirus-infected samples were found in Paty do Alferes (RJ), in spite of a moderately high incidence of whitefly populations associated with tomatoes in that area.

Analysis of the genetic diversity of begomoviruses infecting tomatoes was carried out by direct sequencing of PCR products. This strategy, after the PCR parameters were optimized, was extremely efficient for the analysis of a large number of sequences in a short time. Sequences of up to 500 nucleotides were obtained from each reaction. The sequenced 
TABLE 1 - Detection of begomoviruses in tomato (Lycopersicon esculentum) samples collected in fields located in the states of Minas Gerais (MG), Espírito Santo (ES), and Rio de Janeiro (RJ). Viruses were detected by PCR with universal primers for the DNA-A of begomoviruses

\begin{tabular}{lcc}
\hline \hline Field location & Sample code & $\begin{array}{c}\text { Number (\%) of } \\
\text { PCR positive } \\
\text { samples per field }\end{array}$ \\
\hline Bicas & Bi-C1 to 15 & $10(67)$ \\
Bicas & Bi-F1 to 15 & $13(87)$ \\
Bicas & Bi-G1 to 15 & 0 \\
Igarapé & Ig-A1 to 15 & $5(33)$ \\
Igarapé & Ig-B1 to 15 & $5(33)$ \\
Igarapé & Ig-D1 to 15 & $1(07)$ \\
Mateus Leme & ML-H1 to 15 & $5(33)$ \\
Mateus Leme & ML-E1 to 15 & $11(73)$ \\
Serra Azul & SA-I1 to 15 & $10(67)$ \\
Total MG & & $\mathbf{6 0}(44)$ \\
Várzea Alegre & VA-M1 to 15 & 0 \\
Várzea Alegre & VA-N1 to 15 & $4(27)$ \\
Várzea Alegre & VA-O1 to 15 & $7(47)$ \\
Várzea Alegre & VA-P1 to 15 & $5(33)$ \\
Várzea Alegre & VA-Q1 to 15 & 0 \\
Várzea Alegre & VA-R1 to 15 & $13(87)$ \\
Total ES & & $\mathbf{2 9}(32)$ \\
Paty do Alferes & PA-W1 to 24 & 0 \\
Paty do Alferes & PA-Y1 to 20 & 0 \\
Paty do Alferes & PA-Z1 to 25 & 0 \\
São Fidélis & SF-S1 to 15 & $9(60)$ \\
São Fidélis & SF-T1 to 15 & $5(33)$ \\
São Fidélis & SF-U1 to 15 & $10(67)$ \\
São Fidélis & SF-V1 to 15 & $13(87)$ \\
São Fidélis & SF-X1 to 15 & $11(73)$ \\
Total RJ & & $\mathbf{4 8 ( 3 3 )}$ \\
\hline Total & $\mathbf{1 3 7}(\mathbf{3 7})$ \\
\hline & & \\
\hline
\end{tabular}

region included the 5 '-end of the $c p$ gene (180-210 nucleotides). This is the most variable region of the $c p$ gene, and according to Padidam et al. (1995), is representative of the nucleotide sequence variability of the entire viral genome.
Therefore, a phylogenetic analysis based on this region is usually sufficient to establish the taxonomical position of a given begomovirus isolate.

Among the PCR-positive samples, 35 tomato samples were selected for the phylogenetic analysis, 15 from MG, 8 from ES, 12 from RJ, plus three different weed samples: Sidastrum micranthum Baker, Blainvillea rhomboidea Cass. and wild common bean (Phaseolus vulgaris L.) This selection was made on the basis of the fields where samples were collected (at least two samples from each field) and of the sizes of the PCR fragments amplified, which varied among different samples (data not shown).

Nucleotide sequences of the 38 isolates were compared to begomovirus sequences present in the GenBank database using the BLASTn search tool. For all isolates compared, nucleotide sequence homologies were always below $80 \%$ against other begomoviruses (data not shown), indicating that the Brazilian isolates belong to novel, distinct species.

Pair wise comparisons of the tomato begomovirus sequences indicated a high degree of homology among the viruses present in $\mathrm{MG}$, with the exception of isolates $\mathrm{Bi}-\mathrm{C} 12$, Ig-D3 and Bi-F2 (Table 2). These isolates were also highly homologous to Tomato chlorotic mottle virus (TCMV), a new begomovirus species isolated from Igarapé, MG (Ribeiro et al., 2002). However, when the sequences of TCMV or the other isolates from MG were compared to those from tomato isolates collected in ES or RJ, the degree of homology was considerably lower (Table 2). Comparisons between isolates from EA and RJ indicated a high degree of homology, except for isolates VA-R2, SF-V11 and SF-V15. Together, the results of this initial sequence analysis suggested the existence of two groups of isolates, one present in MG and classified as TCMV, and the other distributed throughout the states of ES and Northern RJ, comprising a distinct begomovirus species. Additionally, possible new species (isolates Bi-C12, Ig-D3, Bi-F2, VA-R2, SF-V11 and SF-V15) were also found.

Phylogenetic analysis confirmed the sequence comparisons. Isolates from RJ and ES were clustered together in the phylogenetic tree, while isolates from MG were clustered in a separate branch of the tree (supported by a

TABLE 2 - Percent nucleotide sequence homology of the 5'-end of the cp gene of tomato (Lycopersicon esculentum) begomoviruses from Southeastern Brasil. Not all isolates sequenced are shown. Isolates marked with (*) and $(* *)$ represent two groups of isolates with greater than $90 \%$ homology within each group

\begin{tabular}{|c|c|c|c|c|c|c|c|c|c|c|c|c|}
\hline & TCMV & Ig-A10* & Bi-C12 & Ig-D3 & Bi-F2 & ML-H5* & SA-I6* & VA-N3** & VA-R2 & SF-S1** & SF-V11 & SF-V15 \\
\hline TCMV & 100 & 97 & 66 & 69 & 80 & 98 & 98 & 79 & 71 & 78 & 69 & 69 \\
\hline Ig-A10* & & 100 & 68 & 71 & 75 & 98 & 98 & 78 & 68 & 77 & 69 & 69 \\
\hline Bi-C12 & & & 100 & 73 & 68 & 68 & 65 & 64 & 75 & 67 & 76 & 83 \\
\hline Ig-D3 & & & & 100 & 71 & 70 & 70 & 72 & 65 & 68 & 73 & 66 \\
\hline Bi-F2 & & & & & 100 & 75 & 76 & 74 & 74 & 76 & 60 & 71 \\
\hline ML-H5* & & & & & & 100 & 98 & 79 & 69 & 77 & 69 & 70 \\
\hline SA-I6* & & & & & & & 100 & 79 & 71 & 76 & 68 & 68 \\
\hline $\mathrm{VA}-\mathrm{N} 3 * *$ & & & & & & & & 100 & 67 & 98 & 71 & 71 \\
\hline VA-R2 & & & & & & & & & 100 & 66 & 71 & 74 \\
\hline SF-S1** & & & & & & & & & & 100 & 76 & 68 \\
\hline SF-V11 & & & & & & & & & & & 100 & 83 \\
\hline SF-V15 & & & & & & & & & & & & 100 \\
\hline
\end{tabular}


bootstrap value of $73 \%$ ), together with the prototype TCMV isolate (Figure 1). These two groups of isolates comprise two distinct begomovirus species. The presence of the same species in $\mathrm{RJ}$ and ES can be explained by the geographical proximity of the locations where samples were collected. The insect vector can probably be transported from one area to the other by wind or in leaves and fruits left in the boxes used for the transport of tomato fruits.

Besides these two groups of isolates, additional distinct isolates were also found. Isolates Bi-F2, Ig-D3 and VA-R2

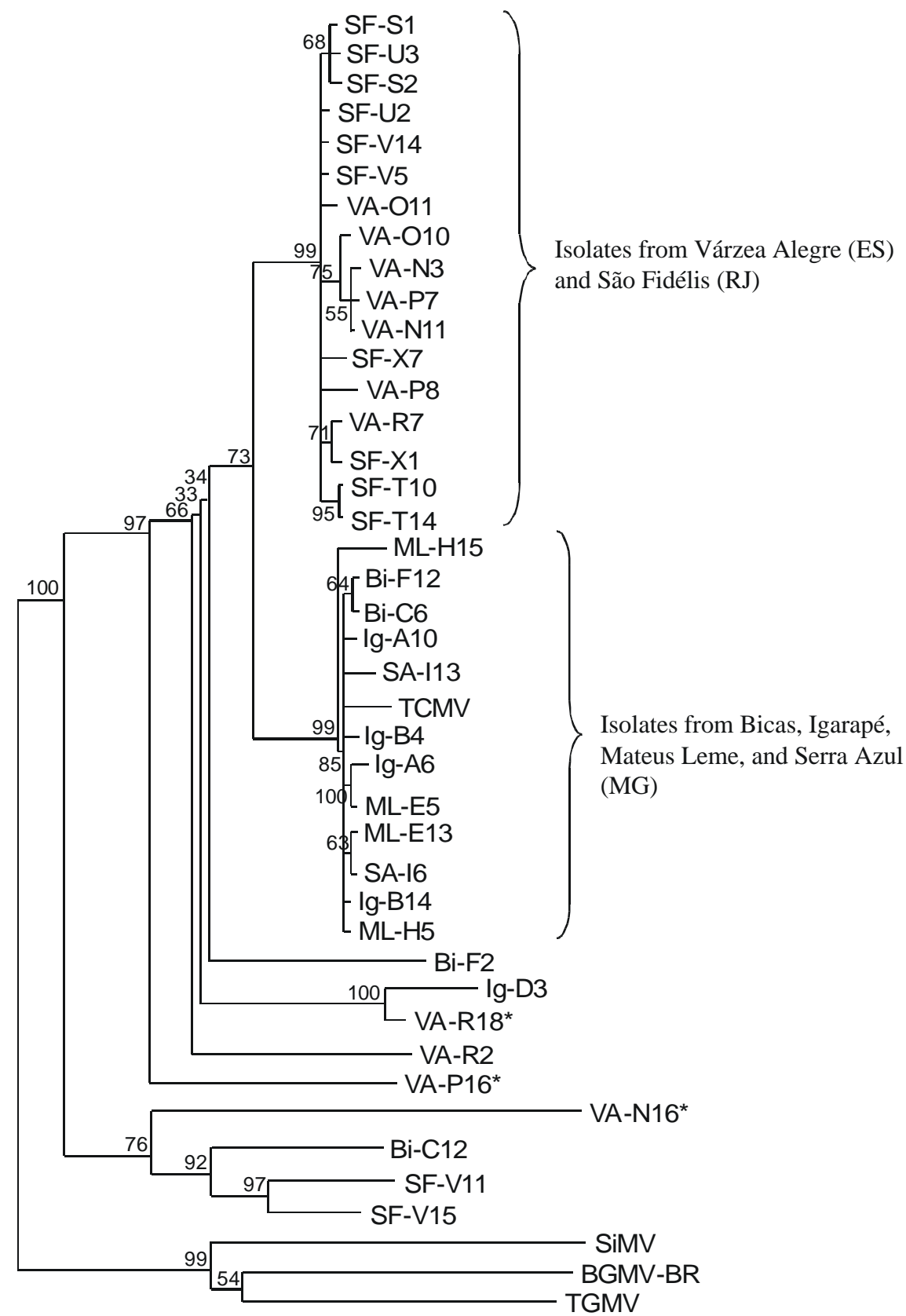

FIG. 1 - Phylogenetic tree prepared with the programs Clustal W and MEGA, indicating the relationship among begomoviruses infecting tomato (Lycopersicon esculentum) and associated weeds collected in Southeastern Brazil. The region used for the analysis corresponds to the 5'-end of the $c p$ gene. Isolates marked with an (*) were obtained from weed samples. Scale " $"$ " is equivalent to a genetic distance of approximately 0,004749 (Nei, 1972). Numbers at each ramification of the tree are the bootstrap values (based on 2000 replications) for each branch of the tree. Tomato chlorotic mottle virus (TCMV), Sida golden mosaic virus (SiGMV), Bean golden mosaic virus (BGMV) and Tomato golden mosaic virus (TGMV). 
were each placed in isolated branches of the phylogenetic tree, while isolates Bi-C12, SF-V11 and SF-V15 were clustered together in the same branch (Figure 1). Therefore, the first three isolates and the group formed by the last three isolates represent four possible new species, which differed from the remaining tomato isolates in the sequence and phylogenetic analyses.

The high degree of genetic diversity among tomato begomoviruses (two definitive species, one in MG and the other in RJ/ES, plus an additional four possible new species) suggests that indigenous viruses are being transferred from natural hosts into tomatoes by the whitefly vector. These viruses have probably been associated with weeds or wild plants, and did not reach the tomato until recently due to the absence of an aggressive vector. Reports of begomovirus infection in weeds and other wild plants can be found in the Brazilian literature as far back as the 1950's (Costa, 1955; Costa, 1976; Costa \& Bennett, 1950). The A biotype of $B$. tabaci, although capable of transmitting begomoviruses, does not normally colonize tomatoes. Conversely, the B biotype readily colonizes this host (Brown et al., 1995). Therefore, after the introduction of the B biotype into Brazil, transfer of the indigenous begomoviruses from natural hosts to tomato became possible.

The possible new species described above were all collected from tomato plants in fields where additional samples, infected by one of the more prevalent species, were found. This indicates that adaptation of the indigenous viruses to the new host is already taking place. This hypothesis is reinforced by the fact that isolate Ig-D3, from tomato, was placed together with the $S$. micranthum isolate VA-R18 in the same branch of the phylogenetic tree (Figure 1). Likewise, isolate VA-N16, obtained from the weed B. rhomboidea, was clustered together with isolates Bi-C12, SF-V11 e SF-V15 in the tree, although the genetic distance between them was considerably high. This phylogenetic relationship among begomoviruses infecting tomato and associated weeds confirms the important role of natural hosts as begomovirus reservoirs and suggests that the tomato viruses are evolving from the weed viruses. Begomoviruses evolve rapidly, due mostly to recombination and pseudorecombination (Roberts \& Stanley, 1994; Hou \& Gilbertson, 1996; Zhou et al., 1997; Frischmuth \& Stanley, 1998; Padidam et al., 1999; Saunders et al., 2001). The emergence of new begomvirus species by recombination between previously existing species has been demonstrated to occur in nature (Zhou et al., 1997; Saunders et al., 2001). In both cases the new virus was more adapted and induced more severe symptoms in its hosts than the parental viruses. In the specific case of the begomoviruses infecting tomatoes in Brazil, however, a more detailed study of the geminiviruses infecting weeds is necessary before this hypothesis can be confirmed.

Breeders working towards the incorporation of begomovirus resistance genes tomato must take into account the high degree of genetic diversity among tomato begomoviruses in Southeastern Brazil. A given resistance gene might be extremely effective against a particular begomovirus species, and totally ineffective against distinct, unrelated species. Also, the rate of evolution of begomoviruses seems to be inordinately fast (Padidam et al., 1999), leading to the quick emergence of new strains or species that might overcome resistance genes. The durability of a resistance based on a single gene is therefore questionable. The genetic diversity of begomoviruses present in additional regions of Brazil should be determined and the prevalence of distinct species or strains identified, in order to orient breeding programs towards resistance to the species prevalent in each region.

\section{ACKNOWLEDGMENTS}

The authors wish to thank Iedo V. Carrijo, Arildo M. Rego, Irineu L. Rodrigues Filho, Enilton N. de Santana and Silvaldo F. Silveira for assistance in collecting samples.

\section{LITERATURE CITED}

BEDFORD, I.D., BRIDDON, R.W., BROWN, J.K., ROSELL, R.C. \& MARKHAM, P.G. Geminivirus transmission and biological characterization of Bemisia tabaci (Gennadius) biotypes from different geographical regions. Annals of Applied Biology 125:311-325. 1994.

BROWN, J.K., FROHLICH, D.R. \& ROSELL, R.C. The sweetpotato or silverleaf whiteflies: Biotypes of Bemisia tabaci or a species complex ? Annual Review of Entomology 40:511-534. 1995.

COSTA, A.S. Studies on Abutilon mosaic in Brazil. Phytopathologische Zeitschrift 24:97-112. 1955.

COSTA, A.S. Whitefly-transmitted plant diseases. Annual Review of Phytopathology 14:429-440. 1976.

COSTA, A.S. \& BENNETT, C.W. Whitefly transmitted mosaic of Euphorbia prunifolia. Phytopathology 40:266-283. 1950.

COSTA, A.S., OLIVEIRA, A.R. \& SILVA, D.M. Transmissão mecânica do mosaico dourado do tomateiro. Fitopatologia Brasileira 6:147. 1975. (Resumo).

DELLAPORTA, S.L., WOOD, J. \& HICKS, J.B. A plant DNA minipreparation: Version II. Plant Molecular Biology Reporter 1:19-21. 1983.

DEVEREUX, J., HAEBERLI, P. \& SMITHIES, O. A comprehensive set of sequence analysis programs for the VAX. Nucleic Acids Research 12:387-395. 1984.

FARIA, J.C., BEZERRA, I.C., ZERBINI, F.M., RIBEIRO, S.G. \& LIMA, M.F. Situação atual das geminiviroses no Brasil. Fitopatologia Brasileira 25:125-137. 2000.

FARIA, J.C. \& ZERBINI, F.M. Família Geminiviridae - taxonomia, replicação e movimento. Revisão Anual de Patologia de Plantas 8:25-65. 2000.

FRANÇA, F.H., VILLAS-BOAS, G.L. \& CASTELO-BRANCO, M. Ocorrência de Bemisia argentifolii Bellows \& Perring (Homoptera:Aleyrodidae) no Distrito Federal. Anais da Sociedade Entomológica do Brasil 25:369-372. 1996.

FRISCHMUTH, T. \& STANLEY, J. Recombination between viral DNA and the transgenic coat protein gene of African cassava mosaic geminivirus. Journal of General Virology 79:1265-1271. 1998.

HANLEY-BOWDOIN, L., SETTLAGE, S.B., OROZCO, B.M., 
Genetic diversity of begomovirus infecting tomato and associated weeds...

NAGAR, S. \& ROBERTSON, D. Geminiviruses: Models for plant DNA replication, transcription, and cell cycle regulation. Critical Reviews in Plant Sciences 18:71-106. 1999.

HOU, Y.M. \& GILBERTSON, R.L. Increased pathogenicity in a pseudorecombinant bipartite geminivirus correlates with intermolecular recombination. Journal of Virology 70:54305436. 1996.

MATYIS, J.C., SILVA, D.M., OLIVEIRA, A.R. \& COSTA, A.S. Purificação e morfologia do vírus do mosaico dourado do tomateiro. Summa Phytopathologica 1:267-275. 1975.

NEI, M. Genetic distance between populations. American Naturalist 106:283-292. 1972.

PADIDAM, M., BEACHY, R.N. \& FAUQUET, C.M. Classification and identification of geminiviruses using sequence comparisons. Journal of General Virology 76:249-263. 1995.

PADIDAM, M., SAWYER, S. \& FAUQUET, C.M. Possible emergence of new geminiviruses by frequent recombination. Virology 265:218-224. 1999.

POLSTON, J.E. \& ANDERSON, P.K. The emergence of whiteflytransmitted geminiviruses in tomato in the Western hemisphere. Plant Disease 81:1358-1369. 1997.

RIBEIRO, S.G., ÁVILA, A.C., BEZERRA, I.C., FERNANDES, J.J., FARIA, J.C., LIMA, M.F., GILBERTSON, R.L., MACIELZAMBOLIM, E. \& ZERBINI, F.M. Widespread occurrence of tomato geminiviruses in Brazil, associated with the new biotype of the whitefly vector. Plant Disease 82:830. 1998.

RIBEIRO, S.G., AMBROZEVICIUS, L.P., ÁVILA, A.C.,
CALEGÁRIO, R.F., FERNANDES, J.J., LIMA, M.F., MELLO, R.N., ROCHA, H. \& ZERBINI, F.M. Distribution and genetic diversity of tomato-infecting geminiviruses in Brazil. Archives of Virology, 2002 (In press).

ROBERTS, S. \& STANLEY, J. Lethal mutations within the conserved stem-loop of African cassava mosaic virus DNA are rapidly corrected by genomic recombination. General Virology 75:3203-3209. 1994.

ROJAS, M.R., GILBERTSON, R.L., RUSSELL, D.R. \& MAXWELL, D.P. Use of degenerate primers in the polymerase chain reaction to detect whitefly-transmitted geminiviruses. Plant Disease 77:340-347. 1993.

SAUNDERS, K., BEDFORD, I.D. \& STANLEY, J. Pathogenicity of a natural recombinant associated with ageratum yellow vein disease: Implications for geminivirus evolution and disease aetiology. Virology 281:38-47. 2001.

VAN REGENMORTEL, M.H.V., FAUQUET, C.M., BISHOP, D.H.L., CARSTENS, E., ESTES, M.K., LEMON, S.M., MANILOFF, J., MAYO, M.A., MCGEOCH, D.J., PRINGLE, C.R. \& WICKNER, R.B. Virus Taxonomy. Seventh Report of the International Committee on Taxonomy of Viruses. Academic Press, San Diego. 2000.

ZHOU, X., LIU, Y., CALVERT, L., MUNOZ, C., OTIM-NAPE, G.W., ROBINSON, D.J. \& HARRISON, B.D. Evidence that DNA-A of a geminivirus associated with severe cassava mosaic disease in Uganda has arisen by interspecific recombination. Journal of General Virology 78:2101-2111. 1997. 